\title{
Induction of $\beta$-adrenergic metaplasticity of LTP requires intact anchoring of PKA
}

\author{
Janlyn R. Hoffman, Nathan J. Brandwein, and Peter V. Nguyen \\ Department of Physiology, University of Alberta School of Medicine, Edmonton, Alberta T6G 2H7, Canada
}

\begin{abstract}
Beta-adrenergic receptors ( $\beta$-ARs) prime hippocampal synapses to stabilize long-term potentiation (LTP). This "metaplasticity" can persist for $1-2 \mathrm{~h}$ after pharmacologic activation of $\beta$-ARs. It requires activation of PKA (cAMP-dependent protein kinase) during $\beta$-AR priming. A-kinase anchoring proteins (AKAPs) tether PKA to downstream signaling proteins. We hypothesized that induction of this metaplasticity requires intact functioning of AKAPs. Acute application of stearated ht31, a membrane-permeant inhibitor of AKAPs, either during $\beta$-AR activation 30 min prior to LTP induction or during LTP induction, attenuated the persistence of LTP. A control, inactive ht31 peptide did not affect $\beta$-AR-mediated metaplasticity. These findings implicate PKA anchoring in the induction of $\beta$-adrenergic metaplasticity of LTP.
\end{abstract}

Long-term potentiation (LTP) is an activity-induced increase in synaptic strength that is a leading cellular mechanism for learning and memory (Bliss and Lomo 1973; Martin et al. 2000). The prior history of synaptic activity can "prime" future alterations in synaptic potency by a process termed "metaplasticity" (Abraham 2008). Activation of beta-adrenergic receptors ( $\beta$-ARs) by isoproterenol (Iso) elicits stable, persistent LTP hours after washout of Iso, and this $\beta$-AR metaplasticity requires activation of PKA during Iso application (Tenorio et al. 2010). Additionally, this PKA requirement is correlated with increased serine-845 (a PKA phosphor-site) phosphorylation of the GluR1 subunit of glutamatergic AMPA receptors (AMPARs) (Tenorio et al. 2010).

A-kinase anchoring proteins (AKAPs) comprise a family of adaptor proteins that can interact with $\beta$-ARs, AMPARs, PKA, and adenylyl cyclase (for review, see Patriarchi et al. 2018) to enable localized, rapid multicomponent signaling following activation of $\beta$-ARs. These AKAPs anchor regulatory subunits of PKA in close proximity to target substrates of CAMP/PKA signaling, thereby enabling robust transduction in the face of diffusible cAMP. Specific AKAPs, such as AKAP5/150 (Zhang et al. 2013) and AKAP12 (gravin) (Havekes et al. 2012), are critical for $\beta$-AR-mediated enhancement of hippocampal LTP following $5-\mathrm{Hz}$ stimulation applied during (Havekes et al. 2012), or immediately after, Iso (Zhang et al. 2013). It is unknown whether the induction of LTP metaplasticity, elicited well after Iso application (Tenorio et al. 2010), requires intact AKAP function. We hypothesize that intact PKA anchoring is critical for inducing stable metaplasticity of LTP following "priming" of $\beta$-ARs.

To address this hypothesis, we acutely applied a stearated, membrane-permeant AKAP inhibitory peptide, ht31, to murine hippocampal slices that were prepared and maintained under conditions described in our previous study (Tenorio et al. 2010). Male C57BL/6 mice (Charles River Laboratories, Canada, aged 7-12 wk) were used in all experiments and were housed at the University of Alberta in accordance with Canadian Council on Animal Care (CCAC) guidelines. Following cervical dislocation and decapitation, hippocampi were extracted, sliced transversely $(400 \mu \mathrm{m}$ thickness), and slices were transferred to an interface chamber (Fine Science Tools, Canada) where they recovered for $\sim 90 \mathrm{~min}$ at $30^{\circ} \mathrm{C}$, aerated with carbogen $\left(95 \% \mathrm{O}_{2} / 5 \% \mathrm{CO}_{2}\right)$. Slices were continuously perfused with artificial cerebrospinal fluid (aCSF)

\section{Corresponding author: peter.nguyen@ualberta.ca}

Article is online at http://www.learnmem.org/cgi/doi/10.1101//m.049635.119.
[124 mM NaCl, $4.4 \mathrm{mM} \mathrm{KCl}, 1.3 \mathrm{mM} \mathrm{MgSO}_{4}, 1 \mathrm{mM} \mathrm{NaH}_{2} \mathrm{PO}_{4}$, $26.2 \mathrm{mM} \mathrm{NaHCO}_{3}, 2.5 \mathrm{mM} \mathrm{CaCl}_{2}$, and $10 \mathrm{mM}$ glucose] at a rate of $1 \mathrm{~mL}$ per minute. Field excitatory postsynaptic potential (fEPSP) recordings were obtained from area CA1 by homosynaptically stimulating the Schaffer collateral-commissural pathway and recording from stratum radiatum. Recording glass microelectrodes were filled with aCSF (resistances of 2-3 M $\Omega$ ), and bipolar nickelchromium electrodes were used for stimulation. fEPSPs were elicited using a stimulus intensity that produced $40 \%$ of maximum amplitudes, at a test stimulation frequency of once per minute (0.08-msec pulse duration). Following $20 \mathrm{~min}$ of baseline recordings, different protocols were administered involving various drug application and/or high-frequency stimulation (HFS) (one train of $100-\mathrm{Hz}, 1-\mathrm{sec}$ train duration). Drug-free control experiments were achieved by monitoring baseline before delivering 100-Hz. Controls were assessed by applying Iso $(10 \mu \mathrm{M})$ for $15 \mathrm{~min}$ followed by a $30-\mathrm{min}$ washout, then $100-\mathrm{Hz}$ stimulation. For some experiments, AKAP inhibitor peptide, ht31 (10 $\mu \mathrm{M}$, Promega), was applied for $25 \mathrm{~min}$, overlapping with $15 \mathrm{~min}$ of Iso (which commenced 5 min after the start of ht31 application; see Fig. 2B below) or with $100-\mathrm{Hz}$ tetanization (see Fig. $2 \mathrm{C}$ below). In experiments where ht31 was applied during Iso, LTP was induced $30 \mathrm{~min}$ after washout of ht31. This was also repeated using the inactive peptide analog, ht31P (10 $\mu \mathrm{M}$, Promega), as well as a PKA inhibitor, KT5720 (KT, Sigma) $(1 \mu \mathrm{M})$, which was dissolved in a stock concentration of $1 \mathrm{mM}$ in dimethylsulfoxide (DMSO).

Experiments were conducted under dimmed light to minimize the photolysis of Iso. Drug experiments were interspersed with drug-free controls. Data were analyzed offline using pCLAMP 10 software (Axon Instrument Inc.). Initial fEPSP slopes were measured as an index of synaptic strength (Johnston and $\mathrm{Wu}$ 1995). Slopes were averaged using a steady baseline recording (prior to $100-\mathrm{Hz}$ ) to obtain a "baseline" mean value for each experiment. All subsequent slopes were expressed as percentages of these baseline mean slopes. Mean fEPSP slopes, measured $100 \mathrm{~min}$ post-100-Hz, were used for inter-group comparisons of synaptic strength. Student's $t$-tests were used for statistical comparisons of

(C) 2019 Hoffman et al. This article is distributed exclusively by Cold Spring Harbor Laboratory Press for the first 12 months after the full-issue publication date (see http://learnmem.cshlp.org/site/misc/terms.xhtml). After 12 months, it is available under a Creative Commons License (AttributionNonCommercial 4.0 International), as described at http://creativecommons. org/licenses/by-nc/4.0/. 
mean fEPSP slopes between two groups. One-way ANOVA and Tukey-Kramer post-hoc tests were used for comparing the significance between three groups (significance level of $P<0.05$ ). All values were standardized to the average baseline slope and reported as mean \pm SEM.

In our previous study (Tenorio et al. 2010), PKA activation was shown to be required for $\beta$-AR-induced priming of enhanced LTP maintenance. Because AKAPs tether PKA regulatory subunits to molecular targets of PKA, we first wanted to confirm the PKA dependence of this metaplasticity, by acutely applying a PKA inhibitor, KT5720 $(1 \mu \mathrm{M})$, during Iso administration prior to $100-\mathrm{Hz}$ induction of LTP (Fig. 1). In slices treated with KT5720 during Iso treatment, the mean fEPSP slope recorded $100 \mathrm{~min}$ after $100-\mathrm{Hz}$ stimulation was $105 \pm 5 \%(n=6)$ of pre-Iso baseline (Fig. 1B); this was significantly less than the mean fEPSP slope recorded from slices treated with Iso and given $100-\mathrm{Hz}$ stimulation $30 \mathrm{~min}$ after Iso washout $(136 \pm 11 \%, n=6, P<0.05$, Fig. $1 \mathrm{~A})$. Slices receiving only $100-\mathrm{Hz}$, without Iso, displayed a mean fEPSP slope of $106 \pm 4 \%$ (Fig. 1A, $n=8$ ), which was significantly less than the mean slope from Iso $+100-\mathrm{Hz}$ slices $(P<0.01)$. Thus, stable $\beta$-AR metaplasticity requires PKA activation during the priming Iso treatment. $\beta$-AR activation by Iso recruits PKA 30-40 min before LTP induction.

We next applied stearated ht31, an inhibitor peptide that blocks the interaction between type RII regulatory subunits of PKA and AKAP (Carr et al. 1992). In slices treated with active ht31 $(10 \mu \mathrm{M})$ during Iso (Fig. $2 \mathrm{~B})$, the mean fEPSP slope was $103 \pm 3 \%(n=7)$ versus $139 \pm 14 \%$ in control slices receiving only Iso $+100-\mathrm{Hz}(n=6$, Fig. $2 \mathrm{~A})$. In contrast, an inactive ht31 peptide $(10 \mu \mathrm{M})$, applied to slices receiving Iso $+100-\mathrm{Hz}$, yielded a mean fEPSP slope of $160 \pm 23 \%$ ( $n=8$, Fig. 2B). An ANOVA comparing differences in fEPSP slopes among a control group and both the active and inactive peptides identified significant differences be- tween groups $\left(F_{(2,18)}=23.3, P<0.00001\right)$ (Fig. 2D). A subsequent Tukey-Kramer post-hoc test revealed that ht31 application impaired induction of metaplasticity of LTP relative to control slices $(P<0.01)$ but not with the inactive peptide $(P>0.05)$. In comparison with the ht31 experiments, the inactive peptide group also exhibited a marked increase in mean fEPSP slope $(P<0.00001)$.

In addition to impairing the induction of metaplasticity of LTP, ht31 may indirectly reduce PKA activation that results from $100-\mathrm{Hz}$ HFS. To test this notion, we shifted the application of ht31 to overlap with HFS. In these experiments (Fig. 2C), ht31 (or ht31P) was applied for $25 \mathrm{~min}$, starting $10 \mathrm{~min}$ prior to HFS and ending $15 \mathrm{~min}$ after HFS. We found that with ht31 (active peptide), the mean fEPSP slope was $100 \pm 5 \%(n=7)$, which was significantly reduced from a mean slope of $131 \pm 10 \%$ in slices treated with ht $31 \mathrm{P}$ control peptide $(n=5 ; P<0.01)$. An ANOVA comparing differences in fEPSP slopes among a control group (Iso minus peptide) and both the active and inactive peptides, identified significant differences between groups $\left(F_{(2,15)}=27.1, P<0.00001\right)$. A subsequent Tukey-Kramer post-hoc test revealed that ht31 application during HFS impaired induction of LTP relative to control slices $(P<0.001)$ but not with the inactive peptide $(P>0.05)$. Furthermore, the control peptide, when applied coincidentally with $100-\mathrm{Hz}$, significantly increased the average fEPSP slope relative to the active form (when also applied during tetanization) $(P<0.00001)$. Our collective data are summarized in the histograms of Figures 1C and 2D, and they indicate that PKA anchoring is critical for induction of $\beta$-adrenergic metaplasticity of LTP. Such anchoring may be associated with, or initiated by, HFS that leads to induction of stable LTP after earlier "priming" of $\beta$-ARs by Iso.

Metaplasticity of LTP following priming of endogenous neuromodulatory receptors may facilitate the formation of associative memories by prolonging the "effective" time window for synaptic
A

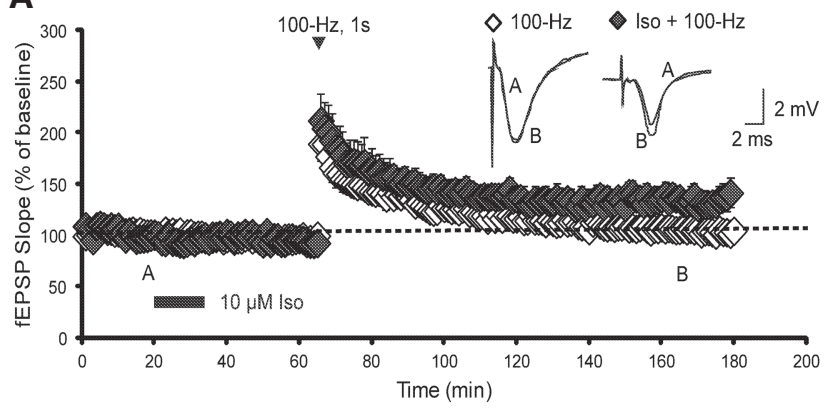

C

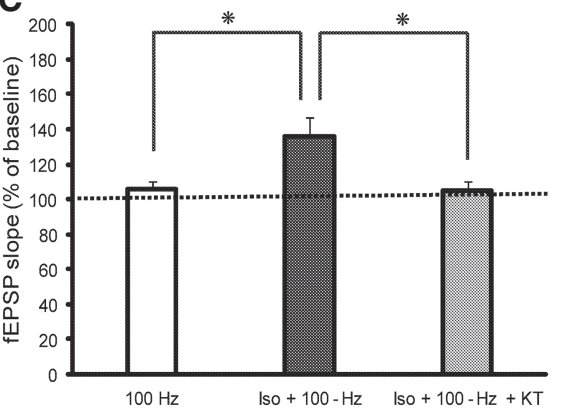

B

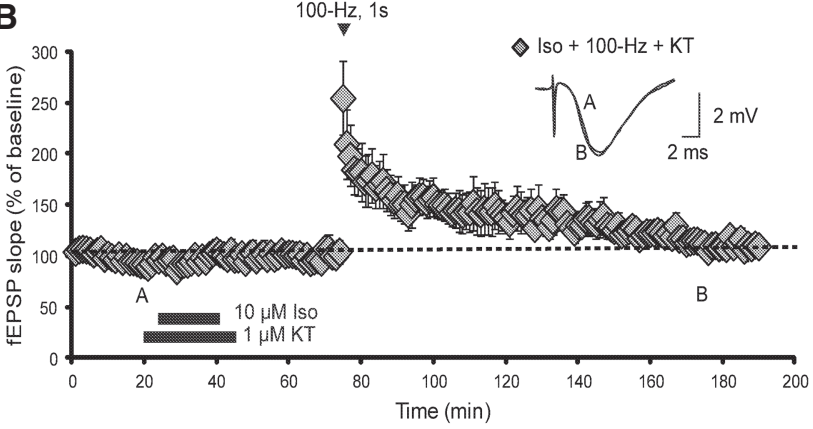

Figure 1. PKA activation is required for metaplasticity of LTP induced by $\beta$-AR stimulation. ( $A$ ) One train of $100-\mathrm{Hz}$ stimulation (1 sec) did not elicit robust long-lasting potentiation in area CA1 (white symbols, $n=8$ ). In contrast, application of Iso (a $\beta$-AR agonist), followed by $100-\mathrm{Hz}$ given 30 min after washout of Iso, induced stable, robust LTP (dark gray symbols, $n=6$ ) that lasted for at least 110 min after induction by 100-Hz. (B) KT5720, a PKA inhibitor, blocked stabilization of LTP when applied during the priming Iso stimulus $(n=6)$. LTP induced by $100-\mathrm{Hz}$ given 30 min after washout of Iso decayed to pre-100-Hz baseline within $100 \mathrm{~min}$ after $100-\mathrm{Hz}$ stimulation. (C) Histogram showing mean fEPSP slopes measured at $100-\mathrm{min}$ post-100-Hz. ${ }^{*}$ represents different $P$ values: $P<0.01$ for $100-\mathrm{Hz}$ versus Iso $+100-\mathrm{Hz} ; P<0.05$ for Iso $+100-\mathrm{Hz}$ versus KT group (light gray bar). Sample fEPSP traces were obtained at time points marked " $A$ " and " $B$ " on $X$-axes of graphs. 
A

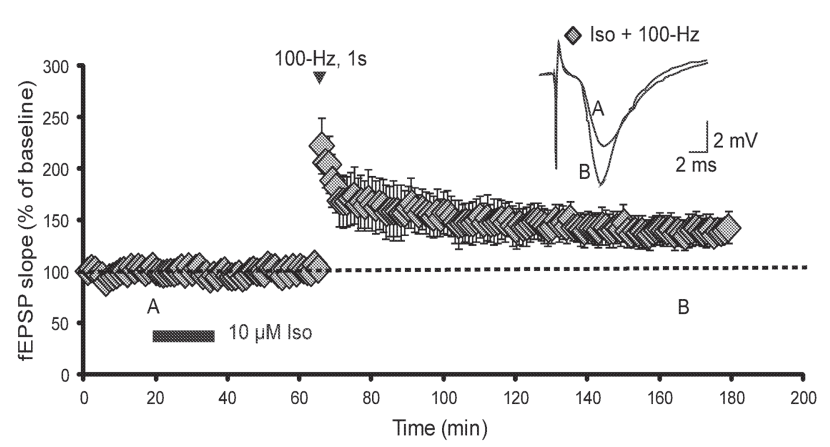

C

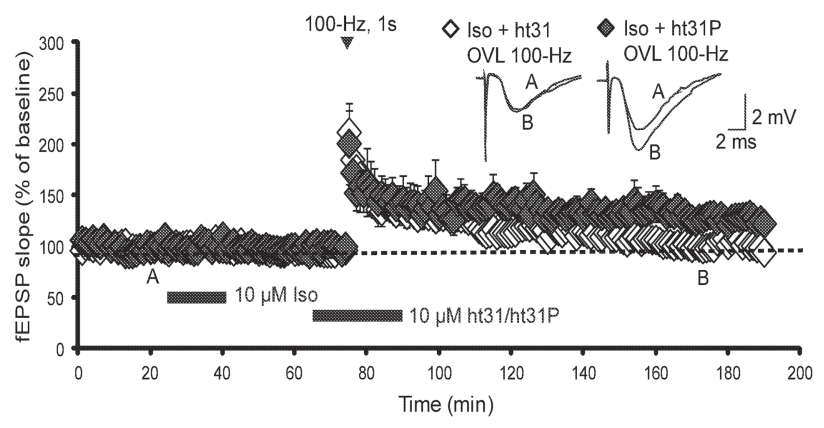

B

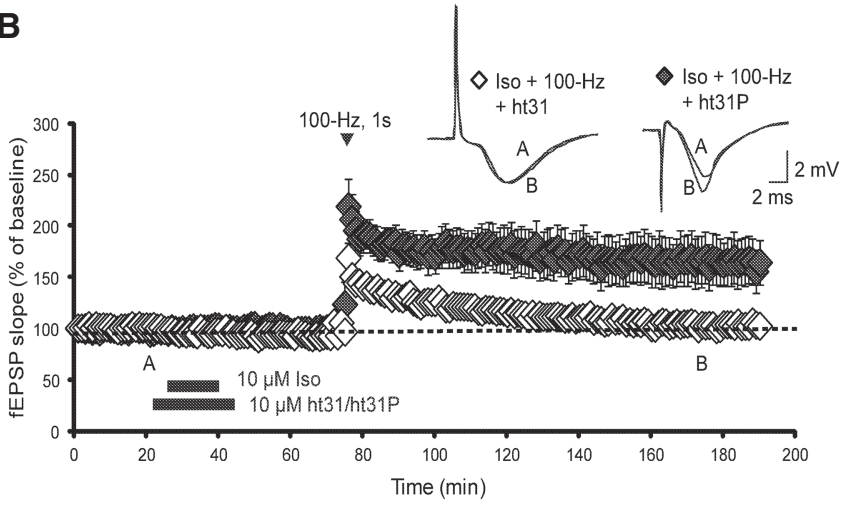

D

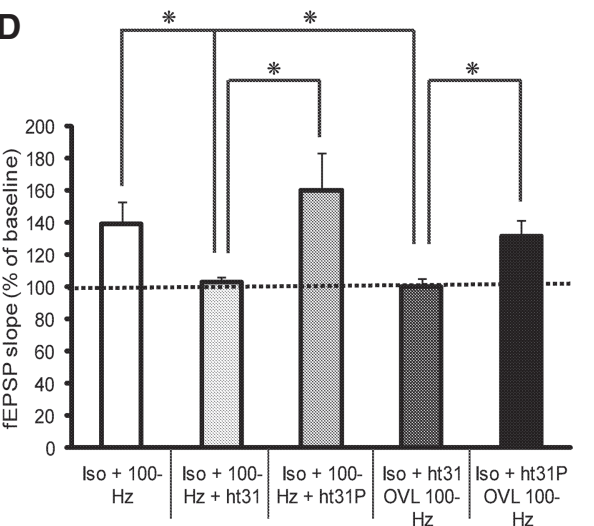

Figure 2. Intact PKA anchoring is required for stable, metaplastic induction of LTP. ( $A$ ) Iso-primed synapses for subsequent long-lasting potentiation induced by $100-\mathrm{Hz}$ given $30 \mathrm{~min}$ after washout of Iso $(n=6)$. (B) Application of stearated ht31 (white symbols, $n=7)$, a peptide inhibitor of AKAPs, during the priming Iso stimulus, blocked LTP maintenance. fEPSPs decayed to pre-100-Hz baseline within 90 min after LTP induction by $100-\mathrm{Hz}$. In contrast, an inactive, stearated ht31 peptide ("ht31P," $n=8$, dark gray symbols) did not affect the stabilization of LTP over the time course of these experiments. (C) Shifting application of the active ht31 peptide (white symbols, $n=7$ ) to overlap ("OVL") with $100-\mathrm{Hz}$ stimulation significantly reduced the longevity of Iso-primed LTP, whereas applying $100-\mathrm{Hz}$ in the presence of ht31P (dark gray symbols, $n=5$ ) had no significant effect. (D) Histogram showing mean fEPSP slopes measured at 100-min post-100- $\mathrm{Hz}$. * represents different $P$ values: $P<0.01$ for Iso $+100-\mathrm{Hz}$ versus Iso $+100-\mathrm{Hz}+\mathrm{ht} 31$ group; $P<0.00001$ for Iso $+100-\mathrm{Hz}+$ ht31 group versus Iso $+100-\mathrm{Hz}+\mathrm{ht} 31 \mathrm{P}$ inactive peptide group; $P<0.001$ for Iso $+100-\mathrm{Hz}$ versus Iso + ht $31 \mathrm{OVL}$ $100-\mathrm{Hz} ; P<0.00001$ for Iso + ht31 OVL 100-Hz versus Iso + ht31P OVL 100-Hz. Sample fEPSP traces were obtained at time points marked "A" and "B" on $x$-axes of graphs.

processing of temporally separated events (Abraham 2008). In our previous study, we showed that $\beta$-AR activation by Iso $1-2 \mathrm{~h}$ before LTP induction can extend the longevity of LTP (Tenorio et al. 2010). This $\beta$-AR-primed metaplasticity required PKA activation during Iso application and it involved phosphorylation of serine-845 on GluR1 subunits of AMPARs, a PKA phosphor-site (Tenorio et al. 2010). However, that study did not examine the relative importance of free, unanchored PKA versus anchored PKA in inducing stable metaplasticity of LTP. Our present results shed light on this issue by revealing that inhibition of AKAP during Iso application impaired the metaplasticity of LTP induced by one $100-\mathrm{Hz}$ train applied $30 \mathrm{~min}$ after Iso washout. By using time-limited bath application of stearated ht31, a peptide inhibitor of AKAPs, we were able to implicate a generic requirement for PKA anchoring in the induction of $\beta$-AR-triggered metaplasticity of LTP. PKA anchoring was also implicated in the maintenance of LTP, as ht31 application during HFS reduced the longevity of LTP (Fig. 2C).

In an earlier study, transgenic, conditional overexpression of ht31in the hippocampi of mice identified a differential requirement for PKA anchoring in distinct forms of LTP and memory: theta-burst LTP and spatial memory required presynaptically anchored PKA, whereas LTP induced by four trains of $100-\mathrm{Hz}$, and spatial learning, required postsynaptically anchored PKA (Nie et al. 2007). Although metaplasticity was not examined in that study, their data complement the growing literature that supports the idea that multiple isoforms of AKAPs (and of PKA: Woo et al. 2000) underlie various forms of synaptic plasticity and mnemonic phenotypes.

AKAPs are adaptor proteins that interact with PSD-95 to assist in assembling a multicomponent complex consisting of PKA, adenylyl cyclase, AMPARs, and $\beta$-ARs (Colledge et al. 2000; Joiner et al. 2010; for review, see Patriarchi et al. 2018). By bringing these signaling elements into close proximity to glutamatergic receptors, AKAPs can facilitate rapid, localized phosphorylation following $\beta$-AR activation. This may help to explain the rapid induction of LTP late after priming of $\beta$-ARs, but it is unclear exactly how such phosphorylation of cell surface receptors causes long-lasting potentiation that can endure for several hours after $100-\mathrm{Hz}$ stimulation in hippocampal slices. Protein synthesis is likely involved, as pharmacologic inhibition of translation significantly reduced the cell surface expression of GluR1-containing AMPARs after $\beta$-AR-induced metaplasticity (Tenorio et al. 2010). Also, serine- 845 phosphorylation (by PKA) on GluR1 persisted for $1-2 \mathrm{~h}$ after washout of Iso (Tenorio et al. 2010). Thus, long-lasting phosphorylation of GluR1 by PKA, along with insertion of GluR1-containing AMPARs, a process that depended on protein synthesis, appears to explain the longevity of metaplastic stabilization of LTP following $\beta$-AR activation. Indeed, a study by Maity et al. (2015), 
identified significantly increased GluR1 mRNA translation in hippocampal extracts of CA1 following noradrenergic metaplasticity of LTP, using an induction protocol similar to the present study. We hypothesize that PKA anchoring may actually play broader roles in affecting synaptic plasticity, by enabling posttranslational modifications of glutamatergic receptors (following $\beta$-AR activation) that can, under appropriate conditions, assist in initiating translation to stabilize LTP (Gelinas and Nguyen 2005; Gelinas et al. 2007; Maity et al. 2015).

Which AKAP isoforms are required for metaplasticity following $\beta$-AR activation? Our data do not permit the identification of specific AKAPs. However, evidence from previous studies provides insights on which AKAPs are likely recruited during Iso-triggered metaplasticity. In the presence of Iso, CA1 LTP induced by thetapulse stimulation was blocked by genetic knockout of AKAP5 in mice (Zhang et al. 2013). Interestingly, a line of mice in which only the PKA-binding site of AKAP5 was deleted (without affecting adenylyl cyclase association with GluR1) displayed less impairment of theta-pulse LTP in the presence of Iso than did AKAP5 KO mice (Zhang et al. 2013). This suggests that AKAP5's anchoring of adenylyl cyclase may also be important for regulating postsynaptic $\beta$-AR signaling. In another study by Havekes et al. (2012), genetic knockout of AKAP12 (gravin) also impaired Iso-induced LTP following theta-pulse stimulation, a deficit apparently linked to altered ERK (extracellular signal-regulated protein kinase) signaling. Unlike our present study, however, these earlier studies did not examine $\beta$-AR-initiated priming with the same 30-min time interval before subsequent $100-\mathrm{Hz}$ LTP induction. From a behavioral perspective, such a protocol may better mimic situations where an organism's hippocampal circuits are primed for plasticity well before a significant event has occurred, but is nonetheless anticipated. Noradrenergic priming may constitute a mnemonic "preparatory" signal that can facilitate future information storage at synaptic contacts engaged by behaviorally salient events occurring well after $\beta$-AR activation.

\section{Acknowledgments}

This research was supported by a Discovery Grant from the Natural Sciences and Engineering Research Council of Canada. We thank S. Rah for his assistance.

\section{References}

Abraham WC. 2008. Metaplasticity-tuning synapses and networks for plasticity. Nat Rev Neurosci 9: 387-399. doi:10.1038/nrn2356

Bliss TV, Lømo T. 1973. Long-lasting potentiation of synaptic transmission in the dentate area of the anaesthetized rabbit following stimulation of the perforant path. J Physiol 232: 331-356. doi:10.1113/jphysiol.1973 .sp010273

Carr DW, Hausken ZE, Fraser ID, Stofko-Hahn RE, Scott JD. 1992. Association of the type-II cAMP-dependent protein kinase with a human thyroid RII-anchoring protein. Cloning and characterization of the RII-binding domain. J Biol Chem 267: 13376-13382.

Colledge M, Dean RA, Scott GK, Langeberg LK, Huganir RL, Scott JD. 2000. Targeting of PKA to glutamate receptors through a MAGUK-AKAP complex. Neuron 27: 107-119. doi:10.1016/S0896-6273(00)00013-1

Gelinas JN, Nguyen PV. 2005. Beta-adrenergic receptor activation facilitates induction of a protein synthesis-dependent late phase of long-term potentiation. J Neurosci 25: 3294-3303. doi:10.1523/JNEUROSCI .4175-04.2005

Gelinas JN, Banko JL, Hou L, Sonenberg N, Weeber EJ, Klann E, Nguyen PV. 2007. ERK and mTOR signaling couple $\beta$-adrenergic receptors to translation initiation machinery to gate induction of protein synthesis-dependent long-term potentiation. J Biol Chem 282: 2752727535. doi:10.1074/jbc.M701077200

Havekes R, Canton DA, Park AJ, Huang T, Nie T, Day JP, Guercio LA, Grimes Q, Luczak V, Gelman IH, et al. 2012. Gravin orchestrates protein kinase $A$ and $\beta 2$-adrenergic receptor signaling critical for synaptic plasticity and memory. J Neurosci 32: 18137-18149. doi:10.1523/ JNEUROSCI.3612-12.2012

Joiner ML, Lisé MF, Yuen EY, Kam AY, Zhang M, Hall DD, Malik ZA, Qian H, Chen Y, Ulrich JD, et al. 2010. Assembly of a $\beta 2$-adrenergic receptorGluR1 signalling complex for localized cAMP signalling. ЕMBO J 29: 482-495. doi:10.1038/emboj.2009.344

Johnston D, Wu SM-S. 1995. Foundations of cellular neurophysiology. MIT Press, Cambridge, MA.

Maity S, Rah S, Sonenberg N, Gkogkas CG, Nguyen PV. 2015. Norepinephrine triggers metaplasticity of LTP by increasing translation of specific mRNAs. Learn Mem 22: 499-508. doi:10.1101/lm.039222.115

Martin SJ, Grimwood PD, Morris RG. 2000. Synaptic plasticity and memory: an evaluation of the hypothesis. Annu Rev Neurosci 23: 649-711. doi:10 1146/annurev.neuro.23.1.649

Nie T, McDonough CB, Huang T, Nguyen PV, Abel T. 2007. Genetic disruption of PKA anchoring reveals a role for compartmentalized kinase signaling in theta-burst long-term potentiation and spatial memory. $J$ Neurosci 27: 10278-10288. doi:10.1523/JNEUROSCI.1602-07.2007

Patriarchi T, Buonarati OR, Hell JW. 2018. Postsynaptic localization and regulation of AMPA receptors and Cav1.2 by $\beta 2$ adrenergic receptor/PKA and $\mathrm{Ca}^{2+} / \mathrm{CaMKII}$ signaling. EMBO J 37: e99771. doi:10.15252/embj .201899771

Tenorio G, Connor SA, Guevremont D, Abraham WC, Williams J, O'Dell TJ, Nguyen PV. 2010. 'Silent' priming of translation-dependent LTP by beta-adrenergic receptors involves phosphorylation and recruitment of AMPA receptors. Learn Mem 17: 627-638. doi:10.1101/lm.1974510

Woo NH, Duffy SN, Abel T, Nguyen PV. 2000. Genetic and pharmacological demonstration of differential recruitment of cAMP-dependent protein kinases by synaptic activity. J Neurophysiol 84: 2739-2745. doi:10.1152/ jn.2000.84.6.2739

Zhang M, Patriarchi T, Stein IS, Qian H, Matt L, Nguyen M, Xiang YK, Hell JW. 2013. Adenylyl cyclase anchoring by a kinase anchor protein AKAP5 (AKAP79/150) is important for postsynaptic beta-adrenergic signaling. J Biol Chem 288: 17918-17931. doi:10.1074/jbc.M112 .449462

Received March 3, 2019; accepted in revised form April 23, 2019. 


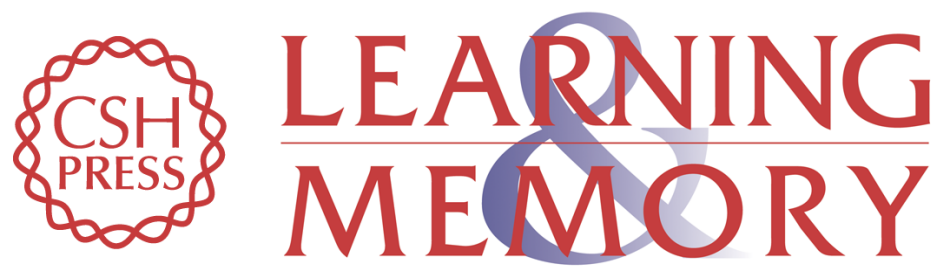

\section{Induction of $\beta$-adrenergic metaplasticity of LTP requires intact anchoring of PKA}

Janlyn R. Hoffman, Nathan J. Brandwein and Peter V. Nguyen

Learn. Mem. 2019, 26:

Access the most recent version at doi:10.1101/Im.049635.119

\begin{aligned} & \hline References $\begin{array}{l}\text { This article cites } 15 \text { articles, } 9 \text { of which can be accessed free at: } \\ \text { http://learnmem.cshlp.org/content/26/6/187.full.html\#ref-list-1 }\end{array} \\ & \begin{array}{r}\text { Creative } \\ \text { Commons } \\ \text { License }\end{array} \begin{array}{l}\text { This article is distributed exclusively by Cold Spring Harbor Laboratory Press for the } \\ \text { first } 12 \text { months after the full-issue publication date (see } \\ \text { http://learnmem.cshlp.org/site/misc/terms.xhtml). After } 12 \text { months, it is available under } \\ \text { a Creative Commons License (Attribution-NonCommercial } 4.0 \text { International), as } \\ \text { described at http://creativecommons.org/licenses/by-nc/4.0/. }\end{array} \\ & \begin{array}{c}\text { Receive free email alerts when new articles cite this article - sign up in the box at the } \\ \text { top right corner of the article or click here. }\end{array} \\ & \begin{array}{l}\text { Service } \\ \text { terting }\end{array}\end{aligned}$

